\title{
WDR66 Gene
}

National Cancer Institute

\section{Source}

National Cancer Institute. WDR66 Gene. NCI Thesaurus. Code C113273.

This gene plays a role in the mediation of protein-protein interactions. 